\title{
Working together: a story-based approach
}

\begin{tabular}{|c|c|}
\hline Leonie Norrington & Jangu Nundhirribulla \\
$\begin{array}{c}\text { College of Indigenous Futures, Arts and } \\
\text { Society, Charles Darwin University }\end{array}$ & $\begin{array}{c}\text { College of Indigenous Futures, Arts and } \\
\text { Society, Charles Darwin University }\end{array}$ \\
\hline leonierobin.norrington@cdu.edu.au & \\
\hline
\end{tabular}

Keywords: history; literature; fiction; Northern Territory; Indigenous; cross-cultural; Science; Technology and Society; cosmopolitics

\begin{abstract}
Increasingly research in North Australia involves generative collaborations between researchers and Aboriginal elders, landowners and knowledge authorities; collaborations that bring people together from multiple and multi-faceted epistemic worlds. My research is located in this space. I am writing a historical novel set in Arnhem Land in the 1600s, before the colonial intrusion. The Traditional Owners of the lands where the story is set are supervising the novel. The historical novel form and the English language of articulation are firmly embedded in a Western world, while the characters, plot and zeitgeist are from the pre-colonial Wubuyspeaking world. Lingering in the dynamic interface between the Wubuy and English-speaking worlds, a place where language and logic grapple to make meaning, and articulate concepts, this article tells the story of a moment of epistemic disconcertment and how working through that disconcertment manifested itself in my research and the writing of the novel. I draw on Helen Verran's proposition that researchers cultivate epistemic disconcertment, and Serres' notion that learning happens when the researcher lingers in the turbulent middle between cultures where all references are equally distant.
\end{abstract}

\section{An Ethnographic Story}

Jangu Nundhirribala, her sister Leonie Murrungun and I, climb into our swag in the flywire tent. The night is dark but when the torchlight goes out, the stars hang bright in the blackness above us. A night birds calls. A bandicoot rustles in the grass; a cane toad calls down by the dam. Jangu and her sister talk to each other in Wubuy language. The sound drifts over me. It takes me back to my childhood, falling to sleep by a campfire in Arnhem Land, the conversation in languages I could not understand, soothing, relaxing. I was just drifting off when Jangu said the Kriol phrase, 'Spirit Child'. They talked again for a long while in language. The melodic rise and fall of their voices settled me again, until I heard 'become human' and the Wubuy word for Spirit Child. I realised they were talking about something that had happened earlier in the night.

Jangu and Leonie are the Nunggubuyu managers of the Macassan time stories of the Numbulwar area. They are supervising the writing of my historical novel. After working in Darwin with me at Charles Darwin University, we were on our way back to their home community of Numbulwar, and we camped overnight with a friend near Katherine. Earlier in the night, while talking about the work we were doing, my friend asked Jangu what a Spirit Child11 was. "Is it like a soul?"

\footnotetext{
1 Spirit Child is a common Kriol phrase that has transferred into the vernacular of North Australia. For discussion of the concept Spirit Child see Merlan (1986).
} 
There was a long uncomfortable silence. Then Jangu had a long discussion with Leonie in Wubuy. Afterward, she looked at me and said, "You tell her." So, I told my friend what I thought Spirit Children were, how they came into being, how they entered and left human forms. I kept catching Jangu and Leonie's eye while I was talking, looking for confirmation. Is this right way to say it? They watched me closely, nodding, "Yuwai" and "Mah" to tell me to continue, or saying "That's the way we believe it" to my friend. Now laying in our swags, they were repeating the English phrases I had used: 'Spirit Child', 'become human,' 'essence.' They were discussing how to explain Spirit Child in English. Jangu works as a Wubuy interpreter in the courts and in government organisations. Leonie works as an interpreter and cultural advisor in education, yet the discussion went on while the moon rose and moved across the sky. I do not speak Wubuy, so I could not understand what they were saying, but there was no hint of mocking or resentment in their voices. I understood that they were discussing how to interpret Spirit Child from Wubuy into English, in earnestness and in good faith.

Until this moment I thought I had a reasonable grasp of what a Spirit Child was. Growing up in Arnhem Land in the 1960s meant growing up in a world saturated with non-human beings. We knew the ground we walked on was alive, that the hawk flying above us might be an Elder who has taken that shape to keep an eye on us. We called out to the ancestors and lifted our faces to have water sprayed over us, so the saliva of the Elders would keep us safe. Although I have never been through women's ceremonies, I was confident that my understanding, although 'young', was correct. Therefore, listening to these skilled translators talk for hours about the subject was disconcerting. Explaining Spirit Child in English was obviously much more complicated than my earlier explanation suggested.

My first reaction was panic. Was my explanation of Spirit Child completely wrong? Had Jangu and Leonie just agreed with my interpretation out of respect or to be polite? ${ }^{2}$ Had they only agreed with me, so as not to shame me in front of my friend? One of the dilemmas of growing up on a remote community is that your adopted family assumes that because you were 'grown up properly' you understand. Yet there are times when you struggle to keep up with the concepts that fashion knowledge you have forgotten or never properly grasped. Most of the time you can stumble on, but because Spirit Children are central to the Wubuy-speaking world I wanted to present in the novel, I felt If I didn't understand Spirit Children how could I hope to write a novel set within a Wubuy-speaking world?

I fell into an exhausted sleep as Jangu and Leonie's deliberations continued and when I woke, I was alive with what the poet Lyn Hejinian calls in her essay 'A rejection of Closure' a Faustian "rage to know"3 (Hejinian, 2002). I wanted to ask Jangu and Leonie if my attempt to explain Spirit Child was right. Could they be more honest with me when we were alone? Or would our friendship ensure that my question elicited more polite agreement? However, asking them to validate the action they had already validated would be considered rude, even between researcher and supervisor so I worried alone. I wondered if perhaps if the question I wanted to ask, 'Was my explanation of Spirit Child right?' was in fact, the wrong question. By identifying myself in the question, am I asking, "Was the explanation I gave to my friend last night the right explanation for someone like me (with youthful knowledge and limited eligibility to know more), to give someone like my friend (an outsider)?" How might I find out if my understanding

\footnotetext{
2 Liberman identifies what he calls 'gratuitous concurrence' as when a research participant agrees with the researcher out of respect, in order to avoid conflict, or to be polite (Liberman, 1980).

3 Faust from the German legend exchanges his soul for access to unlimited knowledge.
} 
was correct? Is there such a thing as a 'correct explanation' of Spirit Child or is it necessarily governed by the speaker and the audience, in the same way as one would explain the concept of time differently to a child, an undergraduate and a quantum physicist?

During the ten-hour drive to Numbulwar I tried to elicit more discussion about Spirit Children. Jangu and Leonie fell asleep to silence me. That silence forced me to wallow in the experience of disconcertment. ${ }^{4}$ Initially I felt frustrated that I was being excluded from knowledge that frank discussion could readily make accessible to me. As the hours passed, I mulled over the words 'translation', 'interpretation' and 'explanation' and I realised that all three words presume equivalence. That led me to consider if it is possible to translate, interpret or explain concepts accurately across epistemological and language boundaries. While there are words for 'spirit' and 'child' in both Wubuy and English, the concepts that surround the words 'spirit' and 'child' are not equivalent in Wubuy and English. The English word 'child' when spoken by someone who has grown up in a western world will bring with it ideas of youth, inexperience, inchoateness, a clean slate, yet to learn. However, the word 'child' to a person raised in a Wubuy-speaking epistemology, while also meaning youth, does not include the idea of inexperience or inchoateness. Embedded in the Kriol word 'child' is the concept of an eternal spirit that has existed in humans from the Dreaming. (Interestingly, writing that last sentence, I almost said 'since', a word embedded in linear time, instead of 'from' the Dreaming.) Likewise, the word 'spirit' in western ways of knowing has both different visual and conceptual realities to what it has in the Wubuy-speaking world. While the noun phrase 'Spirit Child' makes sense for both English and Wubuy speakers, the concept is not held together with the same clots of logic in both ways of knowing.

The next time Jangu, Leonie and I met, we unpacked the meaning of the English words 'spirit' and 'child'. After much discussion, Jangu decided instead of using 'Spirit Child' that we would use 'Eternal Spirit.' She felt that 'Eternal Spirit' was a more didactic description. Spirit Children are discussed throughout the historical novel and I present here three scenes. The first is when a group of women are discussing a child in utero

'Where did the eternal spirit come to you?' her mother asks.

'My husband dreamt it while we stayed at Narridhinbar estuary. We caught and ate green turtle,' she says.

'He'll travel long distances, like a turtle.'

'He might be a Law man.'

'You are the whistling kite,' a mother tells her child. 'Your father dreamed you when we were at Mardjan Mountain near the Whistling Kite dreaming.'

Or another scene where a woman is arguing with her husband;

'The future of the Nunggubuyu people is created inside our women.' Her voice rises. 'Our eternal spirit becomes human inside women.'

'You are a wise woman', Djoli says, lifting his hand for silence. 'But trade is outside your authority.'

4 Helen Verran calls this "lingering in the journey as inchoate experience of experience" (Verran, forthcoming) 
Or another scene when a Lawman is trying to educate his younger brother:

Djoli tries again, 'You remember when the Bayini came from across the seas,' he says, addressing his brother's eternal spirit. 'They showed us how they plant rice. . . They wanted us to be like them.'

When I read these scenes to Jangu and Leonie, they said "Yuwai" and "Mah" to tell me to continue, or said "That's the way now," just as they did when I explained what a Spirit Child was to my friend.

\section{"But what if the reader doesn't understand?"}

Jangu frowned put her hand on my arm and pointed with her lips to the computer, authoritative. "It is right. Please just go on reading the story". It seemed like we had different priorities. I was trying to understand the concepts completely, so that I could potentially find the perfect English words to elicit in the reader a complete knowing. Jangu had faith in the story itself. For Jangu the priority was telling the 'true' story and allowing that experience to facilitate whatever knowledge might be available to the reader.

\section{Analysis}

I came to this situation with the notion that objects have essential identities, real natures that are nameable with words and can be translated from one language to another. However, concepts are "world-making tools" particular to worlds and their knowers (de la Cadena \& Blaser, 2018). Therefore, as researchers we cannot assume it is possible to translate concepts from one world to another. While we can translate 'child' (physical young person) from one language to another, the translation does not necessarily include the concepts that produce the child or childness or child being. Different 'children' are materialised by different configurations of concepts. Although the researcher can only draw from their own knowledge resources, they are able to cultivate an epistemic demeanour that recognises that there are alternative and multiple knowledges, which are just as valid (Verran, 2002). Helen Verran suggests that when people from different epistemic heritages work together, they will often find each other's ways of knowing incomprehensible. However she argues that these inevitable awkward moments are productive, and that they should be lingered in, expanded and provoked (Verran, forthcoming). In The Troubadour of Knowledge, Michel Serres likens this learning space to swimming in the turbulent middle of a river or channel where all reference points are equally distant (Serres, 1997). In this sink or swim space where the mooring of our own knowledge habits, and the knowledge we hope to learn, are equally distant, we are able to interrogate our own ways of knowing (in this case the concepts inherent in the English words 'spirit' and 'child') and find other ways of considering the world (Verran, 2018).

Finding oneself in this space, Isabelle Stengers (2018) suggests that the researcher should reject the habit she has of testing the reality she cannot recognise. Stengers is concerned with recovering the "pragmatic art of immanent attention" in order to include other-than-human participants in a conversation (Stengers, 2018, p.107). Here, I suggest 'recomposing' oneself might be useful in allowing for situations where 'knowing' is not possible. For example, a researcher may not have the credentials to go through a series of women's ceremonies to fully understand the adult Wubuy-speaker's 'Spirit Child'. In this situation she could recompose herself by relinquishing her need to be the testator, and trust her co-participants who are the 
'knowers', to have the final decision (Verran, 2002). While lack of trust is part of the intellectual heritage of the scientific pursuit of 'objective' knowledge, it is also indicative of there being only one 'all-knowing knower.' When we trust electrical engineers to know what they know, we are not only trusting them, but we are putting our faith in a western educational system that is part of our own epistemology. If we want to work productively at epistemological boundaries, where there are two 'all-knowing knowers', we have to trust our participants and their unknowable education system, to be the experts in their field (Verran, 2018).

\section{Conclusion}

Jangu Nundhirribala, Leonie Murrungun and I are working together to produce a historical novel set near their country. We are working across epistemic boundaries; me trying to understand Wubuy-speaking epistemology well enough to recreate it in fiction; them supervising a historical novel, a media that draws on a different epistemic heritage than their own. At moments of real disconcertment when it becomes obvious that our ways of knowing are ruled by incommensurable conceptual difference, it is only our commitment to the outcome that drags us through. This commitment requires us to recognise the other's ontologies, interrogate our own, relinquish our 'all-knowing knower' status as professionals in our respective fields, and to accept that the other's unknowable 'all-knowing' status is as equally valid as our own. This is a complex space, but lingering here facilitates invention and enables our two completely different worlds to move forward together without one diminishing the other.

\section{References}

de la Cadena, M., Blaser, M. (Eds.). (2018). A World of Many Worlds. Durham: Duke University Press.

Hejinian, L. (2002). The Rejection of Closure. In L. Keller (Ed) The Language of Inquiry (pp. 40-58). Berkeley: University of California Press.

Liberman, K. (1980). Ambiguity and gratuitous concurrence in inter-cultural communication. A Journal for Philosophy and the Social Sciences, 3(1), 65-85. doi: 10.1007/BF02331801

Merlan, F. (1986). Australian Aboriginal Conception Beliefs Revisited. Man, 21(3), 474-493. https://doi.org/10.2307/2803097

Serres, M. (1997). The Troubadour of Knowledge. Ann Arbor: University of Michigan Press.

Stengers, I. (2018). The Challenge of Ontological Politics. In M. de la Cadena, \& Blaser, M. (Ed.), A World of Many Worlds (pp. 83 - 111). Durham: Duke University Press.

Verran, H. (2002). A postcolonial moment in science studies: Alternative firing regimes of environmental scientists and Aboriginal landowners. Social Studies of Science, 32(5-6), 729-762. doi: 10.1177/030631270203200506

Verran, H. (2018). The politics of working cosmologies together while keeping them separate. In M. de la Cadena, \& Blaser, M. (Eds.), A World of Many Worlds (pp. 112 - 130). Durham: Duke University Press.

Verran, H. (forthcoming). Writing an Ethnographic Story. In A. Ballestero \& B. R. Winthereik (Eds). The Ethnographic Effect: A Companion to Analysis. Durham and London: Duke University Press 